\title{
INTERPERSONAL GROUP THERAPY TERHADAP PENGETAHUAN DAN PERUBAHAN SIKAP PERLINDUNGAN DIRI DARI IMS PEKERJA SEKS KOMERSIAL JALANAN USIA 15-18 TAHUN DI DENPASAR BALI (The Effect of Interpersonal Group Therapy Toward Knowledge and Attitude of Street Sexual Workers 15-18 years Protection from Sexual Transmitted Infection at Denpasar Bali)
}

\author{
Levi Tina Sari \\ STIKes Patria Husada Blitar \\ e-mail: viemuaniez@yahoo.com
}

\begin{abstract}
The province of Bali with the largest number of foreign tourists to the $9.73 \%$ growth in 2011, became the public and government concern in the case of HIV/AIDS. Denpasar city was ranked to be the first of people with HIV by 1,949 people (KPA province of Bali, 2012). The study on the sex tourism in ASEAN is reported by the Child Wise Tourism Australia in 2007, Indonesia was considered as the destination for sex tourism which involve children and young women. The aim of the study was to analyze the effect of group therapy self-protection knowledge and attitudes of Commercial street sex workers aged 15-18 years. Method: The design used in this study was pre - experimental design with the design of One Group Pre-test - post-test design. The sample of this study was 18 people consisting of 3 groups, each group consisting of 6 persons. Snowball sampling technique was used to the respondents who met the inclusion criteria. Result: Statistical test results using paired $t$ - test sample showed an increase in knowledge on STI, attitudes of self-protection. Knowledge $t=7243$, the attitude of $t=6,803$ with table $=2: 21$. Discussion: The conclusion of this research showed that there were significant effect of the interpersonal group therapy model with knowledge of STI, attitudes of self-protection against STI to the customer. It was suggested that socialization and coaching on the use of condoms should be increased as well as providing sustainable skills in order to become capital for them not to go back into prostitution.
\end{abstract}

Keywords: interpersonal model of group therapy, attitudes, commercial sex workers, sexual transmited infections

\begin{abstract}
Abstrak: Provinsi Bali dengan jumlah wisatawan mancanegara terbesar dengan pertumbuhan 9,73\% pada tahun 2011, sehingga menjadi perhatian publik dan pemerintah dalam kasus IMS khususnya HIV/AIDS. Kota Denpasar masih menduduki peringkat pertama dengan jumlah penderita 1.949 orang (KPA provinsi Bali, 2012). Kajian mengenai wisata seks di ASEAN yang dilaporkan oleh Child Wise Tourism, Australia pada tahun 2007, Indonesia dianggap sebagai negara tujuan wisata seks yang melibatkan anak dan remaja dalam hal ini wanita. Tujuan dari penelitian ini adalah menganalisis terapi kelompok terhadap pengetahuan dan sikap perlindungan diri dari IMS. Metode: Desain penelitian ini adalah pra-eksperimental One Group Pra test - post test Design. Sampel penelitian sebanyak 18 orang yang terdiri dari 3 kelompok, masingmasing kelompok terdiri dari 6 orang. Tehnik pengambilan sampel snowball sampling pada responden yang memenuhi kriteria inklusi. Hasil uji statistik paired sample t-test menunjukkan peningkatan pengetahuan tentang IMS, sikap perlindungan diri terhadap IMS. Ada pengaruh terapi kelompok dengan model interpersonal dengan pengetahuan tentang IMS, sikap perlindungan diri terhadap IMS serta perilaku PSK terhadap perlindungan diri dalam menghadapi pelanggan. Diharapkan adanya sosialisasi dan pembinaan
\end{abstract}


tentang penggunaan kondom serta memberikan ketrampilan yang berkesinambungan agar menjadi modal bagi mereka agar tidak kembali menjadi PSK.

Kata Kunci: terapi kelompok model interpersonal, sikap, PSK, IMS

Perkembangan IMS menunjukkan peningkatan yang tinggi, namun pencegahan dan penanggulangan yang efektif belum diketemukan (Juliandi, et al., 2004). Data bulan Januari sampai Maret 2013, rasio AIDS antara pria dan wanita berbanding 2:1. (Ditjen PP dan PL Kemenkes RI, 2013). Data tersebut disebabkan oleh seorang PSK (Pekerja Seks Komersial) wanita dapat melayani 6 pria dalam semalam dan PSK sangat rentan terhadap IMS. (Kurniawan, 2011).

Propinsi Bali dengan jumlah wisatawan domestik pada tahun 2012 sebesar 6.063 .558 orang, sedangkan jumlah wisatawan mancanegara sebesar 2.892.019 orang, hal ini terlihat wisatawan domestik lebih besar dibandingkan dengan wisatawan mancanegara. Menurut Isfandiari (2012), hanya 10\% dari pelanggan lokal yang menggunakan kondom secara konsisten untuk melindungi dirinya dari resiko penularan IMS, sedangkan menurut Hutomo (2013), pelanggan PSK dari wisatawan mancanegara lebih sering menggunakan kondom.

Provinsi Bali dengan jumlah wisatawan mancanegara terbesar dengan pertumbuhan $9,73 \%$ pada tahun 2011, sehingga menjadi perhatian publik dan pemerintah dalam kasus IMS khususnya HIV/ AIDS. Kota Denpasar masih menduduki peringkat pertama dengan jumlah penderita 1.949 orang (KPA propinsi Bali, 2012). Kajian mengenai wisata seks diASEAN yang dilaporkan oleh Child Wise Tourism, Australia pada tahun 2007, Indonesia dianggap sebagai negara tujuan wisata seks yang melibatkan anak dan remaja dalam hal ini wanita.

Menurut Mboi (2013), menyatakan bahwa pengetahuan IMS dikalangan remaja mencapai 20,6\% dari yang ditargetkan $85 \%$, sehingga dalam beberapa penelitian menyatakan bahwa pemakaian kondom pada Pekerja Seks Komersial hanya 46,7\% dan sekitar $37 \%$ yang mengetahui manfaat penggunaan kondom, dikarenakan para PSK tersebut mempunyai pengetahuan yang rendah tentang IMS, diketemukan sebanyak 53\% Pekerja Seks Komersial hanya mendengar nama penyakitnya dan pemahaman yang masih bercampur antara pengetahuan yang benar dengan mitos yang keliru. (Susilo, 2004; Kentjana, 2009; Tjahayadi, 2009).
Pekerja seks Komersial yang berusia 15-18 tahun merupakan PSK yang masih berusia remaja, dimana remaja pada masa pertengahan yang sudah dapat mengembangkan kemampuan berfikir abstrak namun masih mencari identitas diri, kemudian dengan tempat bekerja mereka yang tidak terlokalisir sehingga menyulitkan kontrol dalam pendataan angka IMS, sehingga PSK langsung tersebut cenderung memiliki angka IMS yang tinggi (Dandona, 2005). Pemerintah dan lembaga non pemerintah seharusnya dilakukan upaya penanganan bersifat preventif, promotif, kuratif dan rehabilitatif.

Upaya tersebut meliputi peningkatan sosialisasi penggunaan kondom dikalangan PSK, peningkatan kontrol dari PSK dalam area kerja dan perubahan kondisi sosial, serta penurunan angka Infeksi Menular Seksual (IMS), namun juga belum sepenuhnya efektif, oleh karena itu, dilakukan suatu terapi kelompok dengan metode interpersonal. Dimana terapi ini berfungsi untuk menumbuhkan kesadaran dan pengertian diri sendiri, memperbaiki hubungan interpersonal, serta perubahan pengetahuan dan sikap (Yosep, 2007), sehingga diharapkan menjadi metode yang efektif untuk dapat merubah pengetahuan dan sikap PSK dalam penggunaan kondom.

Penerapan terapi kelompok dengan model interpersonal belum pernah di lakukan dan terapi kelompok ini belum pernah di gunakan pada kelompok PSK (Pekerja Seks Komersial). Sebelumnya, penerapan terapi kelompok dengan metode lain pernah dilakukan seperti terapi kelompok suportif ekspresif pada pasien kanker yang dilakukan melalui penelitian oleh Yunitri (2012), dengan hasil terjadi penurunan depresi secara bermakna sebesar 9,15 dengan $\rho$ $\leq \alpha 0,05$. Kemudian, terapi kelompok yang dilakukan oleh Sofyandi, dkk. (2012), dengan menerapkan terapi kelompok komunitas terhadap self - concept pada residen. Dengan hasil terjadi peningkatan selfconcept sebesar 19,1\%, dan perubahan terbesar pada dimensi internal yaitu pada aspek tingkah laku sebesar $24 \%$. Adapun penelitian sebelumnya tentang komunikasi terapeutik secara individu (konseling) yang dilakukan oleh Prambudi (2010) yaitu efektifitas komunikasi interpersonal konselor pada penderita HIV/AIDS, dengan hasil adanya hasil 
yang bermakna terhadap peningkatan perubahan sikap untuk mendukung kehidupannya.

Menurut Sundberg (2007), perbandingan antara terapi individual dengan terapi kelompok adalah terapi individual lebih mahal dan tidak menimbulkan insight dalam memperbaiki fungsi-fungsi kognitif dan afektif, identifikasi diri serta peningkatan ketrampilan hubungan sosial di masyarakat sehingga terapi kelompok dengan model interpersonal dijadikan model untuk membangkitkan motivasi bagi kemajuan fungsi-fungsi kognitif dan afektif, oleh karena itu diharapkan Pekerja Seks Komersial wanita jalanan usia 15-18 tahun mempunyai suatu prinsip untuk selalu menggunakan kondom dan dapat meningkatkan kesehatan dalam proses pencegahan penularan infeksi menular seksual dan HIV/AIDS serta mereka juga diharapkan menjadi tentor bagi teman-teman sesama Pekerja seks Komersial untuk berbagi informasi tentang IMS untuk menekan tingkat penularan. Tujuan penelittian adalah Menganalisis pengaruh terapi kelompok terhadap pengetahuan dan sikap perlindungan diri Pekerja seks Komersial jalanan usia 15-18 tahun.

\section{METODE PENELITIAN}

Desain yang digunakan dalam penelitian ini adalah pra-eksperimental. Dengan desain One Group Pra test - post test Design. Populasi dalam penelitian ini adalah PSK (Pekerja Seks Komersial) usia 15-18 tahun di Kecamatan Sanur Denpasar Bali. Sampel dalam penelitian ini adalah sebagian Pekerja Seks Komersial yang berada di Sanur Denpasar Bali yang memiliki kriteria inklusi sebagai berikut: mendapatkan persetujuan dari wali responden, bekerja di daerah Kecamatan Sanur Denpasar, belum pernah bergabung di bawah naungan LSM atau yayasan, responden yang di "booking" Short time. Subjek penelitian ini sebanyak 18 responden yang dibagi menjadi 3 kelompok. Masingmasing kelompok sebanyak 6 responden. Penelitian dilaksanakan 1 minggu 1 sekali selama 5 minggu.

Variabel bebas dalam penelitian ini adalah terapi kelompok dengan model interpersonal, dan variabel terikat adalah pengetahuan PSK jalanan tentang IMS dan sikap perlindungan diri terhadap IMS. Pengukuran pengetahuan tentang IMS dan sikap perlindungan diri menggunakan kuesioner yang sudah di uji validitas dan realibilitas.

Perlakuan yang diberikan adalah terapi kelompok dengan menggunakan metode interpersonal, dimana responden dikumpulkan dan di berikan terapi sebanyak 5 sesi/minggu, setiap sesi berlangsung selama 120 menit diharapkan dapat dapat merubah pengetahuan dan sikap agar terhindar dari IMS. Sebelum perlakuan pada sesi 1, responden diberikan kuesioner untuk mengetahui pengetahuan dan sikap perlindungan diri sebelum perlakuan, dan pada akhir perlakuan yaitu akhir dari sesi ke-5, responden di berikan kuesioner kembali untuk mengetahui pengetahuan dan sikap perlindungan diri.

Analisis data menggunakan uji paired sample $t$-test. variabel pengetahuan tentang IMS dan sikap perlindungan diri masing-masing menggunakan distribusi frekuensi untuk mengetahui kenaikan atau penurunan nilai.

\section{HASIL PENELITIAN}

\section{Karakteristik Responden}

Dari hasil kuesioner didapatkan 18 responden yang memiliki beberapa karakteristik seperti usia, pendidikan, lama menjadi PSK, pernah mendapatkan informasi tentang IMS serta kejelasan tentang informasi tersebut. Responden dalam penelitian ini mempunyai alasan atau motivasi untuk menjadi PSK adalah ekonomi. Responden berasal dari keluarga yang kurang mampu, serta didukung tempat tinggal asli berasal dari beberapa daerah pelosok di luar pulau Bali yang notabenenya kepala keluarga atau orang tua mereka bekerja sebagai buruh.

Tabel 1. Distribusi Karakteristik Responden

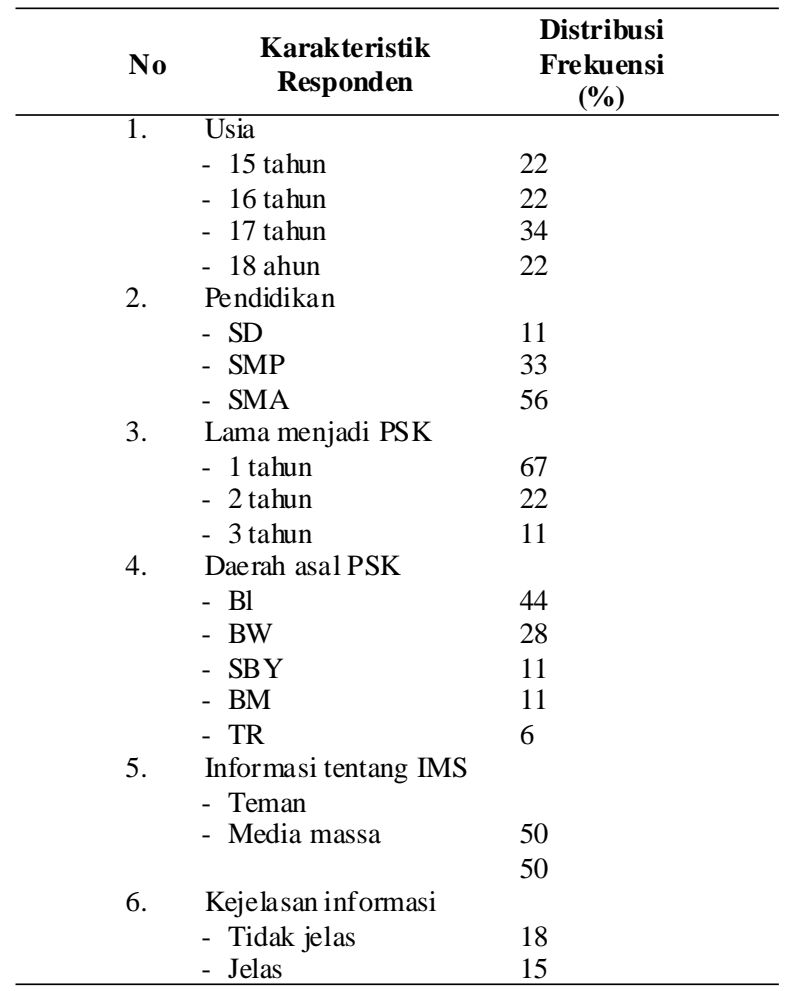


Hasil dari tabel di atas terdapat $34 \%$ responden yang berusia 17 tahun. sebagian besar responden mempunyai jenjang SMA sekitar 56\%. 67\% responden telah menjadi PSK (Pekerja Seks Komersial) selama 1 tahun. daerah asal PSK terbanyak di BL sekitar $44 \%$. sekitar 50\% responden mendapatkan informasi dari temannya dan $50 \%$ responden dari media massa antara lain televisi, radio, buku, koran,dll. 18 responden tidak jelas mendapatkan informasi tentang IMS dan HIV/IDS, yang dikarenakan oleh tidak adanya media disampaikan oleh 3 responden, dan informasi yang disampaikan tidak berkala, disampaikan oleh 15 responden

\section{Pengetahuan Responden tentang IMS}

Tabel 2. Distribusi Frekuensi tentang Pengetahuan terhadap IMS Sebelum dan Sesudah

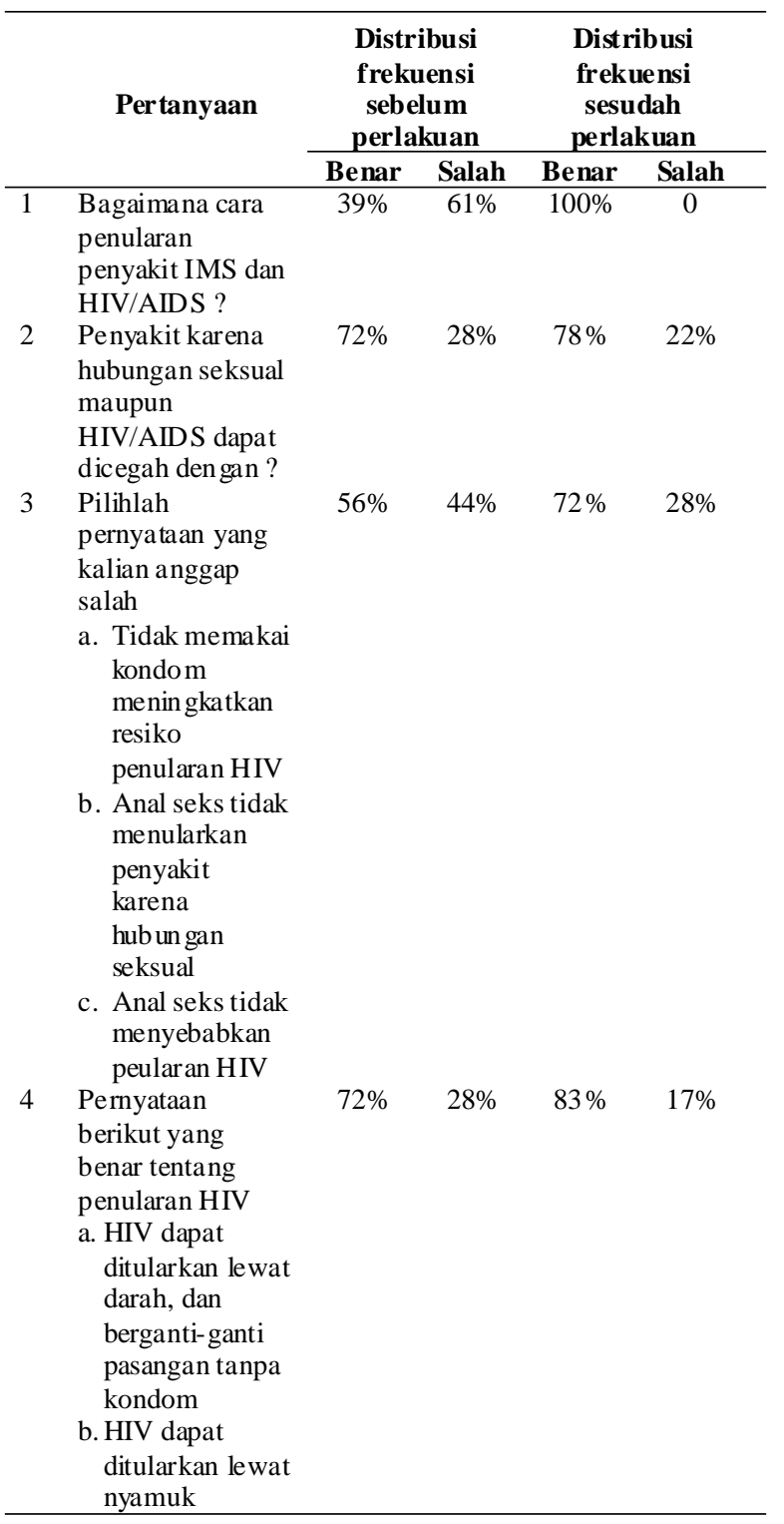

\begin{tabular}{|c|c|c|c|c|c|}
\hline & \multirow[t]{2}{*}{ Pertanyaan } & \multicolumn{2}{|c|}{$\begin{array}{c}\text { Dist ribusi } \\
\text { frekuen si } \\
\text { sebelu m } \\
\text { perlakuan }\end{array}$} & \multicolumn{2}{|c|}{$\begin{array}{c}\text { Distribusi } \\
\text { frekuensi } \\
\text { sesudah } \\
\text { perlakuan }\end{array}$} \\
\hline & & Benar & Salah & Benar & Salah \\
\hline & $\begin{array}{l}\text { c. HIV dapat } \\
\text { di tularkan } \\
\text { jika } \\
\text { bergandeng } \\
\text { an tangan } \\
\text { dengan } \\
\text { OD HA }\end{array}$ & & & & \\
\hline \multirow[t]{2}{*}{5} & $\begin{array}{l}\text { Terjadi luka pada } \\
\text { kulit di dalam di } \\
\text { vagina a tau } \\
\text { dimulut serta } \\
\text { radang saluran } \\
\text { pernapasan atas } \\
\text { (batuk-batu) yang } \\
\text { berulang. }\end{array}$ & $61 \%$ & $39 \%$ & $83 \%$ & $17 \%$ \\
\hline & $\begin{array}{l}\text { Termasuk pada } \\
\text { stadium? }\end{array}$ & & & & \\
\hline 6 & $\begin{array}{l}\text { Apa yang saudara } \\
\text { ke tahui tentang } \\
\text { kondom? }\end{array}$ & $61 \%$ & $39 \%$ & $100 \%$ & 0 \\
\hline 7 & $\begin{array}{l}\text { B agaima na cara } \\
\text { pencegahan } \\
\text { terhadap Infeksi } \\
\text { Menular seksual? }\end{array}$ & $50 \%$ & $50 \%$ & $100 \%$ & 0 \\
\hline 8 & $\begin{array}{l}\text { B agaima na cara } \\
\text { pe makaian } \\
\text { kondom pria? }\end{array}$ & $61 \%$ & $39 \%$ & $83 \%$ & $17 \%$ \\
\hline 9 & $\begin{array}{l}\text { Apa saja Gejala } \\
\text { Infeksi Menular } \\
\text { Seksual pada pria } \\
?\end{array}$ & $44 \%$ & $56 \%$ & $94 \%$ & $6 \%$ \\
\hline 10 & $\begin{array}{l}\text { Apa saja ge jala } \\
\text { terkena HIV ? }\end{array}$ & $61 \%$ & $39 \%$ & $83 \%$ & $17 \%$ \\
\hline 11 & $\begin{array}{l}\text { Golongan atau } \\
\text { kelompok yang } \\
\text { beresiko tinggi } \\
\text { menularkan IMS }\end{array}$ & $44 \%$ & $56 \%$ & $72 \%$ & $28 \%$ \\
\hline 12 & $\begin{array}{l}\text { Faktor-faktor apa } \\
\text { saja yang saudara } \\
\text { ke tahui tentang } \\
\text { terjadinya } \\
\text { peningkatan PMS } \\
\text { ? }\end{array}$ & $78 \%$ & $22 \%$ & $94 \%$ & $6 \%$ \\
\hline 13 & $\begin{array}{l}\text { Bagaimana } \\
\text { pencegahan dari } \\
\text { jengger ayam atau } \\
\text { raja singa? }\end{array}$ & $61 \%$ & $39 \%$ & $72 \%$ & $28 \%$ \\
\hline 14 & $\begin{array}{l}\text { Bagaimana } \\
\text { pencegahan } \\
\text { HIV/AIDS ? }\end{array}$ & $72 \%$ & $28 \%$ & $94 \%$ & $6 \%$ \\
\hline 15 & $\begin{array}{l}\text { Bagaima na } \\
\text { pengobatan dari } \\
\text { Gonore yang } \\
\text { sodara ketahui ? }\end{array}$ & $50 \%$ & $50 \%$ & $83 \%$ & $17 \%$ \\
\hline 16 & $\begin{array}{l}\text { Apa yang saudara } \\
\text { ke tahui tentang } \\
\text { VCT (vo luntary }\end{array}$ & $61 \%$ & $39 \%$ & $89 \%$ & $11 \%$ \\
\hline & $\begin{array}{l}\text { counseling } \\
\text { testing) }\end{array}$ & & & & \\
\hline 17 & $\begin{array}{l}\text { Apa tahapan- } \\
\text { tahapan dari VCT } \\
?\end{array}$ & $61 \%$ & $39 \%$ & $94 \%$ & $6 \%$ \\
\hline 18 & $\begin{array}{l}\text { Apa yang saudara } \\
\text { ketahui tentang } \\
\text { HIV pada stadium } \\
\text { pertama? }\end{array}$ & $61 \%$ & $39 \%$ & $100 \%$ & 0 \\
\hline 19 & $\begin{array}{l}\text { Obat } \\
\text { antire trovirus } \\
\text { adalah }\end{array}$ & $39 \%$ & $61 \%$ & $94 \%$ & $6 \%$ \\
\hline 20 & $\begin{array}{l}\text { Selain } \\
\text { berhubungan seks } \\
\text { dengan kondom } \\
\text { pria. Bagaimana } \\
\text { cara pencegahan } \\
\text { terhadap IMS? }\end{array}$ & $50 \%$ & $50 \%$ & $83 \%$ & $17 \%$ \\
\hline
\end{tabular}


Berdasarkan rincian jawaban responden tentang pengetahuan terhadap IMS dan HIV/AIDS terdapat beberapa item pertanyaan yang mendapatkan nilai paling rendah sebelum perlakuan, diantaranya adalah bagaimana cara penularan penyakit IMS dan HIV/AIDS? (39\%) dan obat antivirus adalah (39\%) serta golongan atau kelompok yang beresiko tinggi menularkan IMS? (44\%). Setelah diberikan perlakuan maka terjadi peningkatan menjadi $100 \%$ untuk pertanyaan bagaimana cara penularan penyakit IMS dan HIV/AIDS? dan 94\% untuk pertanyaan obat antiviris adalah serta $72 \%$ untuk pertanyaan golongan atau kelompok yang beresiko tinggi menularkan IMS?

Tabel 3. Distribusi Frekuensi Kategori Pengetahuan Sebelum Perlakuan dengan Menggunakan Terapi Kelompok Interpersonal

\begin{tabular}{ccc}
\hline $\begin{array}{c}\text { Kategori } \\
\text { Pengetahuan }\end{array}$ & $\begin{array}{c}\text { Distribusi } \\
\text { Frekuensi } \\
(\mathbf{\%})\end{array}$ & $\begin{array}{c}\text { Jumlah } \\
\text { Responden }\end{array}$ \\
\hline Baik & 17 & 3 \\
Cukup & 44 & 8 \\
Kurang & 39 & 7 \\
\hline Total & $\mathbf{1 0 0}$ & $\mathbf{1 8}$ \\
\hline
\end{tabular}

Dari data di atas menunjukkan bahwa sebelum diberikan perlakuan terapi kelompok selama 5 kali terdapat $44 \%$ responden berpengetahuan cukup, dan hanya $17 \%$ responden yang berpengetahuan baik.

Tabel 4. Distribusi Frekuensi Kategori Pengetahuan Sesudah Perlakuan dengan Menggunakan Terapi Kelompok Model Interpersonal

\begin{tabular}{ccc}
\hline $\begin{array}{c}\text { Kategori } \\
\text { Pengetahuan }\end{array}$ & $\begin{array}{c}\text { Distribusi } \\
\text { Frekuensi }\end{array}$ & $\begin{array}{c}\text { Jumlah } \\
\text { Responden }\end{array}$ \\
\hline Baik & 83 & 15 \\
Cukup & 17 & 3 \\
\hline Total & $\mathbf{1 0 0}$ & $\mathbf{1 8}$ \\
\hline
\end{tabular}

Setelah melakukan perlakuan dengn terapi kelompok model interpersonal, didapatkan sebagian besar responden berpengetahuan baik yaitu $83 \%$.

Berdasarkan tabel 5. Terjadi kenaikan rata-rata pada sebelum dan sesudah intervensi sebesar 6 poin. Hasil uji didapatkan nilai $\mathrm{p}<\alpha$ berarti terdapat pebedaan yang signifikan pengetahuan sebelum dan sesudah.
Tabel 5. Nilai Numerik Deskriptif dan Uji Paired T-test dari Pengetahuan Responden Sebelum Intervensi dan Sesudah Intervensi

\begin{tabular}{lccccc}
\hline & N & $\begin{array}{c}\text { Rata- } \\
\text { rata }\end{array}$ & $\begin{array}{c}\text { Simpangan } \\
\text { baku }\end{array}$ & $\begin{array}{c}\text { Rata-rata } \pm \\
\text { simpangan } \\
\text { baku } \\
\text { perbedaan }\end{array}$ & p \\
\hline $\begin{array}{l}\text { Sebelum } \\
\text { perlakuan }\end{array}$ & 18 & 11,56 & 2,640 & $6,000 \pm$ & $<0,0001$ \\
$\begin{array}{l}\text { Sesudah } \\
\text { perlakuan }\end{array}$ & 18 & 17,56 & 1,653 & 3,515 & \\
\hline
\end{tabular}

\section{Sikap Pekerja Seks Komersial}

Berdasarkan rincian jawaban dari responden terdapat beberapa pertanyaan yaitu "Jika saya terkena Gonorhea, maka saya tetap menerima tamu namun sperma dikeluarkan di luar (Coitus Interuptus)" menjawab sangat setuju sebesar $17 \%$ dan menjawab setuju sebesar $28 \%$. Setelah dilakukan terapi kelompok meningkat menjadi jawaban tidak setuju sebesar $44 \%$ dan sangat tidak setuju sebesar $17 \%$. Pernyataan tentang Jika saya tertular IMS (Gonorhea, Chlamydia, atau sifilis), maka saya akan meminta kepada pelanggan untuk menggunakan kondom sebesar 28\% pada poin tidak setuju, namun setelah diberikan perlakuan meningkat menjadi $39 \%$ pada poin sangat setuju.

Dari data tabel 7 membuktikan bahwa sebagian responden mempunyai sikap yang cukup tentang perlindungan diri terhadap IMS sebesar 50\%.

Dari data tabel 8 diketahui bahwa responden yang memiliki sikap baik dan cukup terhadap perlindungan diri terhadap IMS dan HIV/AIDS sebesar $50 \%$. Menurut dari hasil evaluasi di ketahui bahwa responden yang masih satu tahun bekerja mempunyai pendapat tidak ingin kehilangan pelanggan.

Berdasarkan tabel 9. Terjadi kenaikan rata-rata pada sebelum dan sesudah intervensi sebesar 5 poin. Hasil uji didapatkan nilai $\mathrm{p}<\alpha$ berarti terdapat perbedaan yang signifikan sikap sebelum dan sesudah.

\section{PEMBAHASAN}

\section{Karakteristik Responden}

\section{Umur Responden}

Usia atau umur adalah jumlah hari, bulan dan tahun yang telah dilalui sejak lahir hingga waktu tertentu. Umur juga dapat diartikan sebagai satuan waktu yang mengukur waktu keberadaan suatu benda atau makhluk baik yang hidup maupun yang mati. 
Tabel 6. Distribusi Frekuensi tentang Sikap Perlindungan Diri terhadap IMS dan HIV/AIDS Sebelum dan Sesudah Perlakuan

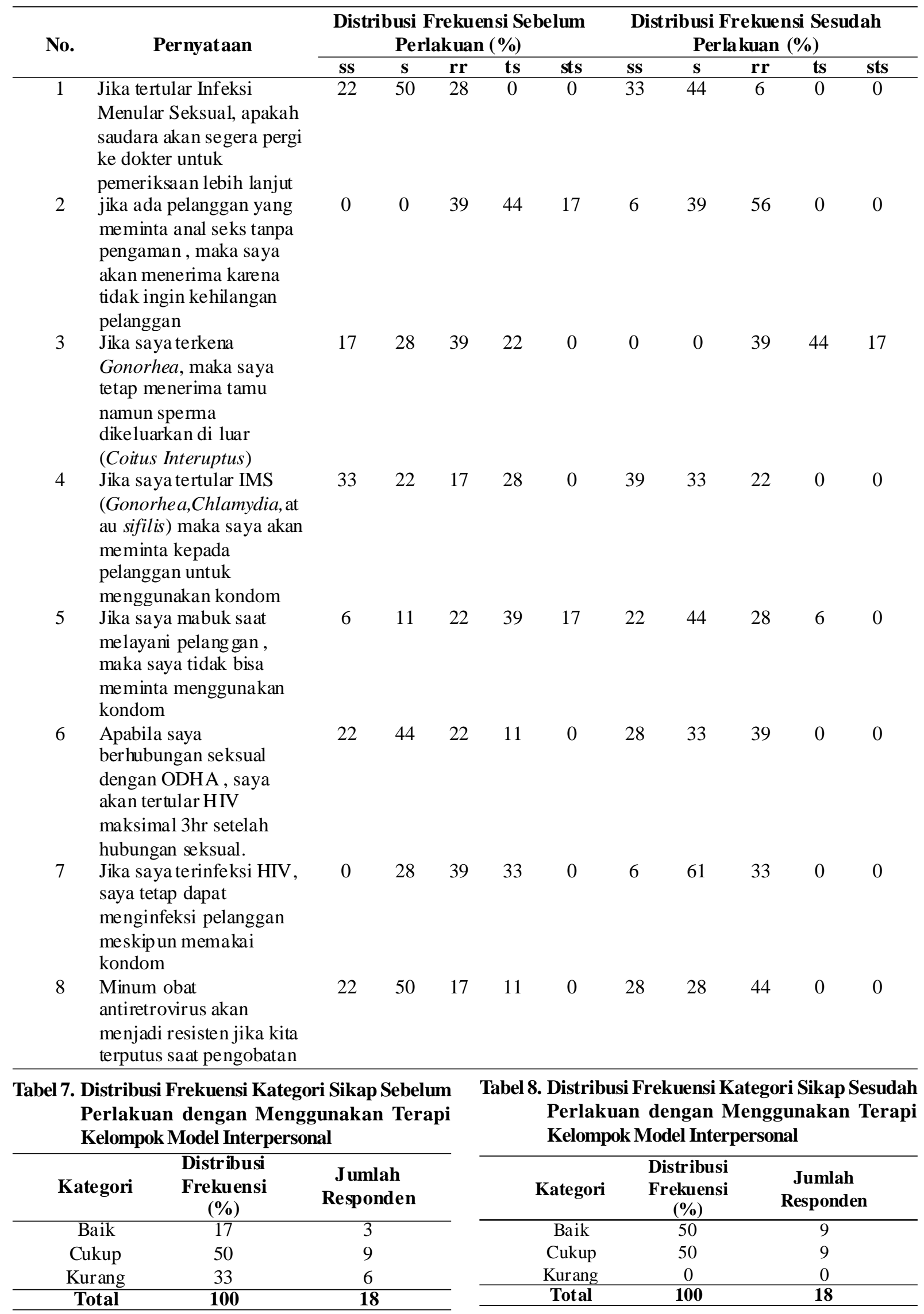


Tabel 9. Nilai Numerik Deskriptif dan Uji Paired T-test dari Sikap Responden Sebelum Intervensi dan Sesudah Intervensi

\begin{tabular}{lccccc}
\hline & N & Rata-Rata & Simpangan Baku & $\begin{array}{c}\text { Rata-Rata } \pm \text { Simpangan } \\
\text { Baku Perbedaan }\end{array}$ & P \\
\hline $\begin{array}{l}\text { Sebelum } \\
\text { perlakuan }\end{array}$ & 18 & 26.06 & 4.544 & $5,444 \pm 1,688$ & $<0,0001$ \\
$\begin{array}{l}\text { Sesudah } \\
\text { perlakuan }\end{array}$ & 18 & 31.06 & 2.127 & & \\
\hline
\end{tabular}

Diketahui bahwa usia reproduksi manusia khususnya wanita ditinjau dari aspek biologis adalah \pm 12-55 tahun. Fase perkembangan dan pertumbuhan pada remaja usia 11-18 tahun (Hurlock, 2008), sedangkan usia produktif untuk bekerja adalah 17 55 tahun. Data dari hasil penelitian PSK yang berusia 15 tahun sekitar 4 responden, usia 16 tahun sekitar 4 responden, usia 17 tahun sekitar 6 responden dan 18 tahun sekitar 4 responden.

Secara fisik PSK yang berusia 15-18 tahun tidak layak untuk bekerja, namun mereka tidak bisa menolak kepada mucikari karena terlilit hutang, mulai dari hutang transportasi dan hutang perawatan tubuh. Beberapa PSK juga mempunyai tanggungan keluarga karena rata-rata mereka berasal dari daerah luar Bali dan berada pada tingkat ekonomi yang rendah.

\section{Pendidikan}

Tingkat pendidikan dalam penelitian ini digolongkan menjadi tiga kategori yaitu rendah, dan tinggi atau tingkat pendidikan 9 tahun (SD s/d SMP) dan SMA. Dari hasil penelitian ini diketahui bahwa SD 2 responden (11\%), SMP 6 Responden (33\%) dan SMA 10 responden $(56 \%)$.

Pendidikan menurut Notoadmodjo (2003), adalah suatu proses belajar yang berarti dalam pendidikan itu terjadi pertumbuhan, perkembangan, dan perubahan kearah yang lebih dewasa atau lebih baik dan lebih matang pada diri individu, kelompok atau masyarakat yang tingkat pendidikan formalnya rendah. Pendidikan menurut Blum (1974), merupakan faktor kedua terbesar setelah lingkungan yang mempengaruhi pengetahuan dan sikap seseorang. Salah satu ciri pendidikan adalah bahwa perubahan itu terjadi karena usaha sadar dan bukan karena kebetulan atau paksaan (koertion) semata. Menurut Departemen Kesehatan (2007), angka penggunaan kondom yang rendah tidak berhubungan dengan tingkat pendidikan atau pengetahuan seseorang mengenai IMS, bagaimana virus ini ditularkan dan bagaimana pencegahannya, melainkan pada pengetahuan tentang kondom dan kesadaran diri seseorang akan perilaku apa yang terbaik untuk dirinya.

Responden pada penelitian ini sudah bisa membaca dan menulis sehingga mereka sudah mengetahui beberapa iklan tentang IMS, namun mereka belum mempunyai kesadaran akan pentingnya kebersihan dan kesehatan diri seperti pentingnya menggunakan kondom pria, hal ini dikarenakan responden belum mendapatkan bimbingan dari layanan kesehatan reproduksi baik dari pemerintah maupun dari swasta (LSM).

\section{Lama Menjadi PSK}

Dalam penelitian ini lama bekerja PSK digolongkan menjadi tiga, yaitu 1 tahun, 2 tahun, dan 3 tahun. Hasil penelitian ini menunjukkan bahwa 1 tahun sebanyak $67 \%, 2$ tahun sekitar $22 \%$ dan sisanya $11 \%$ sekitar 3 tahun. Hasil observasi dan wawancara responden yang bekerja 3 tahun, sudah mengetahui tentang kondom. Namun, karena beberapa responden menggunakan kondom lebih dari satu terhadap pelanggan sehingga sering menimbulkan kesalah pahaman pelanggan dan kebanyakan berlaku kasar terhadap responden, oleh karena itu, untuk selanjutnya beberapa responden tidak menggunakan kondom.

Beberapa responden yang lama bekerja antara 1-2 tahun tidak berani untuk menolak dari kemauan pelanggan karena takut kehilangan pelanggan yang menyebabkan pemasukan berkurang dan tidak dapat membayar hutang kepada mucikari, maka terdapat beberapa responden yang tidak menggunakan kondom. Menurut hasil penelitian saat terapi kelompok berlangsung, terdapat beberapa responden yang menggunakan kondom namun mudah sobek hal ini di karenakan kualitas dari kondom dan penggunaan yang tidak benar, selain itu, menurut Wirawan (2013), menyatakan bahwa saat ini di Bali belum ada peraturan yang tegas berkaitan dengan keharusan menggunakan kondom pada setiap transaksi seksual di kalangan Pekerja Seks Komersial. 


\section{Motivasi Menjadi PSK}

Keputusan subjek menjadi wanita pekerja seks komersial dipengaruhi oleh beberapa faktor yaitu faktor ekonomi dan faktor lingkungan (Subadra, 2007). Hasil penelitian terbukti bahwa motivasi responden usia 15-18 tahun menjadi PSK adalah semua responden masalah ekonomi. Alasan responden pada awalnya ingin menjadi pembantu rumah tangga namun pada akhirnya mereka harus menjadi PSK dengan hutang yang banyak kepada germo sehingga mereka harus mengembalikannya, bahkan ada yang secara sadar menjadi PSK karena disebabkan oleh ekonomi keluarga yang kurang. Awalnya mereka merasa tidak nyaman namun setelah dijalani mereka dapat beradaptasi, bahkan ada yang merasa ketagihan sampai suka dengan salah satu pelanggannya. Menurut Heimstra \& Farling dalam Jajuli (2010), semakin sering mereka melakukan pekerjaan itu (PSK) maka akan terjadi pembiasaan fisik sehingga terjadi pembiasaan psikis yang disebut adaptasi.

PSK usia 15-18 tahun menurut Sarwono (2007), mempunyai khayalan tentang aktivitas seks dan mempunyai perasaan cinta yang mendalam. Ditambahkan pemahaman tentang ilmu agama yang rendah sehingga memudahkan mereka menjadi PSK. Pemerintah Provinsi Bali dengan Dinas Sosial saat ini sudah melakukan sosialisasi, penyadaran dan sidak ke cafe remang serta tempat hiburan malam lainnya. Namun, menurut Wenten (2014), Pemerintah Provinsi Jawa Timur telah menutup lokalisasi sehingga terjadi eksodus PSK dari Jawa Timur ke Bali yang disulit dikendalikan oleh pemerintah Bali. Alasan PSK ke Bali karena Bali merupakan tujuan pariwisata dan PSK tumbuh subur disana.

\section{Asal Daerah Responden}

Data pada hasil penelitian menunjukkan bahwa PSK yang berasal dari daerah BL sebanyak $44 \%$, BW 28\%, SBY dan BM 11\%, serta dari TR $6 \%$. Data tersebut menunjukkan bahwa seluruh responden berasal dari luar daerah Bali. Mereka bekerja di Bali berawal dari ekonomi dan menginginkan kehidupan yang layak. Beberapa responden yang berkeinginan untuk mendapatkan pelanggan, mereka cenderung berpindah tempat kerja, sehingga penghasilan mereka meningkat. Hal ini sangat berpotensi untuk mempercepat penyebaran IMS.

Pihak pemerintah Bali sudah berupaya untuk mengendalikan masuknya PSK ke Bali namun, hal ini sangat sulit sekali karena kebanyakan mereka beralasan untuk berwisata di Bali. Data dari hasil wawancara peneliti saat terapi kelompok berlangsung, Pekerja Seks Komersial sebagian besar beralasan dengan keluarganya untuk bekerja di luar negeri seperti Malaysia dan Hongkong agar mereka diperbolehkan untuk bekerja.

\section{Pengetahuan}

Responden berusia 15-18 tahun merupakan masa remaja pertengahan. Menurut Sarwono (2010), bahwa masa remaja pada tingkat ini sudah dapat mengembangkan kemampuan berpikir, di mana remaja usia menengah pada umumnya mengembangkan kapasitas untuk berfikir abstrak, menikmati kekuatan intelektual dan perhatian pada filosofi, politik, dan masalah sosial.

Sebelum diberikan perlakuan terapi kelompok selama 5 kali hanya 3 responden yang berpengetahuan baik. Hasil tersebut dipengaruhi oleh informasi yang didapatkan sebelum dilakukan terapi kelompok kurang jelas dan tidak bertahap, serta responden mempunyai beberapa opini tentang IMS yang salah karena berdasarkan mitos yang berkembang di masyarakat, seperti cara pengobatan keputihan melalui pembasuhan dengan air daun sirih.

Pengetahuan merupakan hasil dari penginderaan terhadap suatu objek. Hersey \& Blanchard dalam Endah (2003), menyatakan bahwa dalam teori berubah, perubahan yang paling mudah adalah pengetahuan. Terapi kelompok dengan model interpersonal memanfaatkan beberapa media seperti modul dan leaflet serta peserta yang saling mendukung merupakan suatu strategi yang memberikan pengaruh primer. Anggapan dasar dari terapi kelompok adalah mengembangkan berfikir secara logis dan rasional serta objektif dalam mengambil keputusan untuk hasil yang terbaik. Terapi kelompok dengan model interpersonal, untuk intervensi pada kognitifnya bertujuan saling memberikan informasi, gagasan, motivasi dan saran kepada sesama peserta.

Hasil yang didapat setelah perlakuan dengan terapi kelompok model interpersonal yaitu sebagian besar responden berpengetahuan baik yaitu $83 \%$. Pengetahuan yang meningkat setelah dilakukan terapi kelompok secara teori dapat dikaitkan dengan pendidikan. Notoadmodjo (2007) berpendapat bahwa semakin tinggi pendidikan seseorang maka akan semakin mudah menerima atau menyesuaikan dengan hal baru. Pendidikan mempengaruhi proses belajar seseorang, maka seseorang dengan pendidikan tinggi akan cenderung lebih mudah memperoleh banyak informasi. Sebagian besar pendidikan 
responden adalah SMA. Perubahan pengetahuan juga dipengaruhi oleh lingkungan saat terapi kelompok. Lingkungan adalah segala sesuatu yang ada di sekitar individu, baik lingkungan fisik, biologis, maupun sosial. Lingkungan berpengaruh terhadap proses masuknya pengetahuan ke dalam individu yang berada dalam lingkungan tersebut. Hal ini terjadi karena adanya interaksi timbal balik ataupun tidak yang akan direspon sebagai pengetahuan oleh setiap individu. Terapi kelompok dengan model interpersonal bertujuan untuk Pekerja Seks Komersial dapat mempunyai tambahan atau masukan pengetahuan tentang infeksi menular seksual, sehingga responden dapat mengetahui beberapa hal tentang tentang gejala serta pemakaian kondom yang benar.

Hasil dari penelitian yang menunjukkan bahwa terdapat peningkatan pengetahuan. Pengetahuan dalam katagori baik sebesar $83 \%$ dan terdapat $17 \%$ dalam katagori cukup. Menurut hasil penelitian IAKMI (2010) di Bali yaitu pengetahuan yang cukup tentang IMS dan cara pencegahannya belum tentu berimplikasi pada kepatuhan pelaku yaitu pelanggan dan WPS untuk secara konsisten memakai kondom. Dilihat dari beberapa jawaban responden, beberapa soal yang mempunyai nilai terendah yaitu tentang anal seks tidak menularkan penyakit karena hubungan seksual, dan pencegahan dari jengger ayam atau raja singa, hal ini dikarenakan oleh responden tidak menghiraukan penyakit tersebut karena masih bisa diobati dan responden masih mempercayai mitos yang berlaku di masyarakat. Ketidaktahuan responden tentang IMS karena informasi yang diterima masih kurang serta beberapa responden merasa bahwa setiap profesi mempunyai resiko dan mereka menerima resiko tersebut. Pertanyaan tersebut akan menjadi acuan bagi pemerintah dan lembaga non pemerintah untuk lebih di fokuskan agar mereka tidak salah pengertian, selain terdapat salah satu responden dengan pendidikan SMA termasuk dalam kategori cukup, hal ini disebabkan oleh lama bekerja menjadi PSK baru satu tahun dan berasal dari pelosok daerah yang minim akan informasi. Pengetahuan seseorang biasanya diperoleh dari pengalaman yang berasal dari berbagai macam sumber seperti, media poster, kerabat dekat, media massa, media elektronik, buku petunjuk, petugas kesehatan, dan sebagainya. Pengetahuan dapat membentuk keyakinan tertentu, sehingga seseorang berperilaku sesuai dengan keyakinannya tersebut (Istiari, 2000). Diperkuat oleh penelitian dari Afiatin (2004), bahwa ada signnifikasi antara pengalaman dengan pengetahuan, karena pengalaman telah dialami, direfleksi, dan dikonsep dengan kehidupan sehari-hari (transfer of learning).

Menurut tabel 5.4 telah terbukti bahwa terdapat pengaruh terapi kelompok dengan tehnik interpersonal terhadap peningkatan pengetahuan, sehingga terdapat perbedaan antara sebelum dan sesudah perlakuan terapi kelompok dengan tehnik interpersonal. Hasil tersebut dapat dipengaruhi oleh usia responden yang masih muda yaitu 15-18 tahun, sehingga informasi yang diterima dapat dengan mudah dipahami, dikarena kan pada usia tersebut kemampuan intelektual, pemecahan masalah, dan kemampuan verbal hampir tidak terjadi penurunan. Menurut Abu Ahmadi (2001) mengemukakan bahwa memang daya ingat seseorang itu salah satunya dipengaruhi oleh usia. Selain itu responden sebelumnya juga telah mendapatkan informasi tentang IMS. Informasi yang diperoleh baik dari pendidikan formal maupun non formal dapat memberikan pengaruh jangka pendek (immediate impact) sehingga menghasilkan perubahan atau peningkatan pengetahuan. Informasi diperoleh berasal dari teman maupun media massa. Media massa membawa pula pesan-pesan yang berisi sugesti yang dapat mengarahkan opini seseorang maka dapat mempengaruhi pengetahuan mereka. Sarana yang disediakan saat terapi kelompok seperti leaflet juga membantu responden untuk memahami tentang IMS. Hal ini sebanding dengan penelitian dari Dewi (2008), bahwa adanya peningkatan pengetahuan yang signifikan kelompok intervensi setelah diberikan pendidikan kesehatan ( $p$ value $=0,000$ ). Peningkatan pengetahuan yang didapatkan melalui metode peer education akan memberikan tambahan informasi tentang HIV/AIDS.

Salah satu hasil tabel 5.4 tersebut terlihat terdapat kenaikan dan penurunan pada pengetahuan setelah diberikannya terapi kelompok. Menurut pengamatan dari peneliti, kenaikan pengetahuan pada beberapa responden disebabkan karena faktor lamanya menjadi PSK sehingga mereka sudah terbiasa dan mengerti tentang IMS dan cara pencegahannya, kemudian pendidikan serta informasi yang didapat sebelumnya melalui iklan dan media massa serta berpengaruhnya suasana terapi kelompok dengan teman-teman yang saling mendukung saling bertukar cerita dan pengalaman. Pengetahuan responden yang tidak berubah atau menurun, hal ini disebakan oleh beberapa responden kurang pengalaman dan baru menjadi PSK, sehingga tidak banyak mendapat informasi. 
Di lain pihak menurut Helweg-Larsen dalam Kring (2007), mengungkapkan pengetahuan yang sebenarnya dapat menjadi hambatan. Hal tersebut ada beberapa kondisi pengetahuan yang mungkin akan menjadi akibat yang negatif. Sehingga perlu dilakukan tindakan penyuluhan atau pemberian pengetahuan yang berkala oleh pemerintah daerah setempat dan LSM yang menjangkau PSK tidak terorganisir. Harapannya bahwa tidak ada perbedaan persepsi pengetahuan pada PSK.

\section{Sikap}

Sikap merupakan tanggapan seseorang yang masih tertutup terhadap stimulus atau objek. Menurut Alport (1954) dalam Notoadmodjo (2007) sikap mempunyai tiga komponen yang terdiri dari kepercayaan, ide, dan konsep terhadap sesuatu objek, kehidupan emosional atau evaluasi terhadap sesuatu objek, serta kecenderungan untuk bertindak. Terapi kelompok dengan model interpersonal diterapkan melalui beberapa tahap. Tahap awal terapis dan co terapis serta antar peserta terapi harus saling mengenal dan membina hubungan saling percaya sehingga dapat menimbulkan suatu permasalahan yang sedang dihadapi oleh peserta untuk memperoleh keputusan yang benar dalam pencegahan penularan IMS.

Menurut Wright \& Leahay (1994) merupakan sub kategori yang mendasari ide, pendapat dan asumsi yang dimiliki individu. Perubahan pada pengetahuan merupakan perantara perubahan sikap dan perilaku seseorang. Terapi kelompok dimana membuat responden untuk saling bercerita tentang pengalaman menjadi seorang PSK. Sebelum dilakukan terapi kelompok sikap responden dalam perlindungan diri terhadap IMS terdapat kategori kurang sebesar $33 \%$ atau 6 responden

Setiap manusia begitu juga responden menpunyai rasa takut terhadap IMS sangat besar tetapi belum cukup bagi responden untuk melakukan pencegahan secara maksimal. Hal ini dikarenakan beberapa hal yaitu PSK masih usia remaja, dimana mereka tidak mampu menolak keinginan dari pelanggan bahkan jika pelanggan tidak menggunakan kondom, maka responden menurutinya karena tidak ingin kehilangan pelanggan yang akan mengurangi pendapatan mereka. Selain itu, lama bekerja juga mempengaruhi sikap, di mana responden ingin mencari nama hingga dikenal di kalangan pelanggan. Berdasarkan teori adaptasi apabila tingkat pengetahuan baik setidaknya dapat mendorong untuk mempunyai sikap dan perilaku yang baik pula (Widodo, 2005). Dengan adanya pengetahuan tentang IMS maka muncullah sikap yang berupa kesadaran dan niat untuk menggunakan kondom.

Setelah dilakukan perlakuan terapi kelompok dengan model interpersonal sebanyak 5 kali selama 5 minggu di dapatkan hasil sikap yang baik terhadap pencegahan IMS sebesar 50\% dan sikap yang cukup juga sebesar 50\%. Sikap seseorang dapat berubah dengan diperolehnya tambahan informasi tentang objek tersebut, melalui persuasi serta tekanan dari kelompok sosialnya (Sarwono, 1999). Menurut Gerungan (1991), sikap itu selain dipengaruhi oleh faktor internal juga dipengaruhi oleh faktor eksternal, yaitu interaksi kelompok dan komunikasi, oleh karena itu, kelompok atau lingkungan sekitar dapat merubah sikap seseorang.

Hasil dari tabel 7 dan 8 terbukti terdapat perbedaan antara sebelum dan sesudah perlakuan terapi kelompok dengan tehnik interpersonal, di mana terdapat peningkatan sikap sebelum dan sesudah perlakuan, meskipun terdapat beberapa responden yang tidak mengalami kenaikan. Tidak adanya peningkatan tersebut menurut pengamatan peneliti disebabkan oleh responden berkeyakinan jika tidak memakai kondom mereka tidak akan mendapatkan pelanggan, karena mereka belum lama menjadi PSK, dan beberapa responden berpendapat jika menjadi PSK sudah resiko mereka sehingga mereka akan menerima resiko tertular IMS. Responden yang mengalami peningkatan sikap dengan berkeyakinan akan menggunakan kondom dalam setiap transaksi dengan pelanggan, dikarenakan responden ingin hidup lebih lama dan tidak ingin menularkan IMS ke semua pelanggannya, sehingga mereka akan menjadi PSK yang bersih dengan harga yang mahal. Hal tersebut karena responden yang sudah berpengalaman dan sudah lama bekerja menjadi PSK serta dilihat dari mereka yang berusia 17-18 tahun, di mana usia tersebut sudah terjadi kematangan untuk berpikir dan dapat berpikir secara abstrak (Santrock, 2003).

Terapi kelompok model interpersonal mempunyai peranan dalam merubah sikap seseorang, karena dalam terapi kelompok terdapat sosialisasi serta membangkitkan motivasi untuk kemajuan fungsi kognitif dan afektif (Purwaningsih, 2010). Sikap bisa terbentuk dari adanya interaksi sosial yang dialami oleh individu. Dalam interaksi terjadi hubungan saling mempengaruhi diantara individu yang satu dengan yang lain terutama selama proses 
mendapat perlakuan sehingga terjadi hubungan timbal balik yang ikut mempengaruhi sikap masingmasing. Dalam interaksi sosial inilah individu bereaksi membentuk pola sikap yang baru sesuai dengan obyek atau informasi yang diterima yakni Pencegahan IMS. Sikap merupakan sesuatu yang dapat dipelajari, tidak dibawa sejak lahir, tidak menetap dan dapat berubah karena kesiapan bertindak didasarkan pada pandangan dan pendapat yang dibentuk oleh nilai dan keyakinan yang dimiliki seseorang (Mubarak, 2009). Sedangkan dalam Notoadmodjo (2003), sikap merupakan reaksi/respon atau kecenderungan seseorang tehadap suatu objek yang diamatinya, sehingga pengetahuan PSK yang baik tentang IMS saja tidak cukup untuk terbentuknya perilaku pencegahan penularan IMS apabila tidak didukung oleh sikap yang baik pula. Menurut hasil penelitian Budiono (2011) di Argorejo Semarang yang menunjukkan bahwa sikap WPS berpengaruh terhadap praktik penggunaan kondom pada PSK maupun pelanggannya $(\mathrm{p}=0,0001)$. Begitu juga hasil penelitian Evianty (2008) menyatakan bahwa sikap berpengaruh terhadap tindakan PSK untuk menggunakan kondom $(p=0,048)$. Artinya, PSK yang mempunyai sikap baik dalam hal perlindungan diri terhadap IMS akan mempunyai suatu niat yang kuat untuk dapat mempengaruhi pelanggan dalam penggunaan kondom pada saat berhubungan seksual. Sikap untuk menggunakan kondom akan lebih baik jika berawal dari niat, kesadaran sendiri dan adanya pengetahuan yang dimiliki oleh yang bersangkutan. Oleh karena itu harus ada dukungan penuh oleh pemerintah dalam mensosialisasikan pencegahan secara terus-menerus terhadap IMS kepada mucikari/germo dan PSK dalam penggunaan kondom.

\section{SIMPULAN dan SARAN}

\section{Simpulan}

Ada pengaruh terapi kelompok dengan model interpersonal dengan pengetahuan tentang IMS, sikap perlindungan diri terhadap IMS serta perilaku PSK terhadap perlindungan diri dalam menghadapi pelanggan.

\section{Saran}

Diharapkan adanya sosialisasi dan pembinaan tentang penggunaan kondom serta memberikan ketrampilan yang berkesinambungan agar menjadi modal bagi mereka agar tidak kembali menjadi PSK.

\section{DAFTAR RUJUKAN}

Afiatin. T. 2004. Pengaruh Program Kelompok AJI Dalam Peningkatan Harga Diri, Asertivitas, Dan Pengetahuan Mengenai NAPZA Untuk Prevensi Penyalahgunaan NAPZA Pada Remaja. Jurnal Psikologi Fakultas Psikologi Universitas Gajah Mada Nomor 1. Yogyakarta.

Akhmadi, A. 2008. Konseling Kesehatan Remaja: Kajian Materi Diklat Teknis Fungsional Peningkatan Kompetensi Guru Pertama BK MTs. Yogyakarta: Lumbung Pustaka UNY.

ASEAN Child - Sex Tourism Review. 2007. Child Wise Tourism Report. http:www.childwise.net. 13 Februari 2013.

Badan Koordinasi Keluarga Berencana Nasional. 2012. Mitos-mitos Seputar PMS. Http://www.bkkbn. go.id.hqweb/ceria/pengelolaceria/pp3pms.html. 13 Februari 2013.

Budiono, I. 2011. Konsistensi Penggunaan Kondom oleh Wanita Pekerja Seks/Pelanggannya, Jurnal Kesehatan Masyarakat/ KEMAS 7 (2): Hal. 8994.

Dandona, R., Dandona, L., dan Gutierrez, J.P. 2005. High risk of HIV in non-brothel based female sex workers in India. BMC Public Health. India, 5:87.

Direktorat Jenderal Pengendalian Penyakit dan Penyehatan Lingkungan Kementrian Kesehatan RI 2013, Laporan Situasi Perkembangan HIV/AIDS di Indonesia Sampai Dengan Maret 2013, Jakarta. http:// www.spiritia.or.id/Stats/StatCurr.php?lang=id \&gg=1. Mei 2013

Departemen Kesehatan Republik Indonesia. 2003. Kesehatan Reproduksi. DEPKES RI, Jakarta.

Dewi, S. 2008. Pengaruh Pendidikan Kesehatan Dalam Pencegahan HIV/AIDS. Media Ners Fakultas Kedokteran Universitas Diponegoro Volume 2, Nomor 1, Mei 2008. Semarang

Dharma, K.K. 2011. Metodologi Penelitian Keperawatan: Panduan Melaksanakan dan Menerapkan Hasil Penelitian. Jakarta: Trans infomedia.

Evianty, R. 2008. Pengaruh Faktor Predisposisi, Pendukung dan Penguat Terhadap Tindakan PSK dalam Menggunakan Kondom untuk Pencegahan HIV/AIDS di Lokalisasi Teleju Kota Pekan Baru. Tesis. Program Pascasarjana Universitas Sumatra Utara. Medan.

Fitriana, Y.L. 2009. Studi Kasus Perilaku Wanita Pekerja Seksual Tidak Langsung dalam Pencegahan IMS, HIV dan AIDS di PUB dan Karaoke, café, dan Diskotek di Kota Semarang. Tesis. Semarang: Magister Promodi Kesehatan. Universitas Diponegoro.

Holmes, C.B., Losina, E., Walensky, R.P., Yazdanpanah, Y., Freedberg, K.A. 2003. Review of Human Immunodeficiency Virus Type 1-Related Opportunistic 
Infections in Sub-Saharan Africa. Clin. Infect. Dis. 36(5):656-662

Hukumonline. 2007. Menyoroti Sisi Gelap Child Trafficking di Indramayu. http://Hukumonline.com/detail. asp?id=10805\&et=fokus. 13 Februari 2013.

Hurlock, E. 2008. Psikologi Perkembangan Suatu Pendekatan sepanjang Rentang Kehidupan. Jakarta: Erlangga.

Isfandiari, A. 2012. Laporan Perkembangan Pencapaian Tujuan Pembangunan Milenium Indonesia. http:/ /www.academia.edu. 20 Mei 2013.

KPA provinsi Bali. 2012. PSK di Bali Terinfeksi HIV/AIDS. http://bola.okezone.com. 15 Februari 2013.

Kring, dkk. 2007. Abnormal Psychology. Edisi 10. John Wiley \& Sons, Inc. United State of Amerika.

Kurniawan, R. 2011.Komunitas Peduli Penderita HIV/ AIDS. Yayasan AIDS Indonesia. http://www. cafeberita.com. 15 Februari 2013.

Mboi, N. 2013. Jumlah Remaja Paham HIV/AIDS Masih Minim. http://wwwRepublika.co.id. 1 Agustus 2013.

Mudjijono. 2005. SARKEM Reproduksi Sosial Pelacuran. Yogyakarta: Gadjah Mada University Press,

Prambudi, A. 2011. Komunikasi Interpersonal Pada Konseling HIV/AIDS (Studi Deskriptif Keefektivitasan Komunikasi Interpersonal Konselor Dengan Penderita HIV/AIDS Pada Konseling di VCT RSUD Prof Dr Margono Soekardjo Purwokerto). Vol. 6, No.1, FISIPOL. Yogyakarta: Universitas Muhamadiyah Yogyakarta.
Subadara, I.N. 2007. Bali Tourism Watch: Keberadaan Pekerja Seks Komersial Sebagai Dampak Negative Pariwisata di Bali. http://www.subadara. wordpress.com. 13 Februari 2013.

Susilo, H. 2004. Faktor-Faktor yang Mempengaruhi Praktik Negoisasi Penggunaan Kondom Untuk mencegah IMS \& HIV/AIDS pada WPS di Resosialisasi Argorejo Kelurahan Kalibanteng kulon Kecamatan Semarang Barat Kota Semarang. Tesis. Program Pasca Sarjana Universitas Diponegoro, Semarang.

Sundberg, Norman, D., dan Winerbager. 2007. Psikologi Klinis Perkembangan Teori, Praktik dan Penelitian. Yogjakarta: Pustaka Pelajar.

Townsend. 2009. Essentials of Psychiatric Mental Health Nursing $\left(5^{\text {th }}\right.$ ed). Philadelphia: FA. Davis Company.

Tjahayadi, D. 2009. Efektivitas Penyuluhan terhadap Perilaku Mencegah Penularan HIV dan AIDS Pada PSK. Lampung: Badan Kependudukan dan Keluarga Berencana Nasional.

Trisnadi. 2004. Dolly Hitam Putih Prostitusi, Jakarta: Gagas Media.

UNAIDS. 2001. Special Session of the General Assembly on HIV/AIDS Round table 3 Socio-economic impact of the epidemic and the strengthening of national capacities to combat HIV/AIDS (PDF). 18 Januari 2013.

WIKIPEDIA. 2013. Pelacuran. http://id.wikipedia.org/ wiki/pelacuran\#pelacur.13 Februari 2013.

Wirawan. 2012.Penderita HIV/AIDS di Bali Mayoritas PSK. Dinas kesehatan provinsi Bali.http://www. waspada.co.id. 18 Januari 2013. 